\title{
Globalisation, Glocalisation and Community Uncertainties A Qualitative Research Study at Roşia Montană, Romania
}

\author{
Mihai Pascaru \\ University “1 Decembrie 1918” from Alba Iulia \\ Roxana Plesa \\ University of Petroşani, Romania
}

doi: 10.19044/esj.2016.v12n32p20 URL:http://dx.doi.org/10.19044/esj.2016.v12n32p20

\begin{abstract}
The study examines Roşia Montană inhabitants' opinions, attitudes and the "mutations" of the representations generated by Roşia Montană Gold Corporations' retrenchment of economic activity. Our hypothesis is that the retrenchment of activities and the ensuing layoffs are the result of the wrong choice of globalisation strategy that the company attempted in 2013 rather than continuing the glocalisation strategy which proved successful up to that point. The study presents the main themes of a 2014 qualitative research survey namely: 1) the rift between the private and the public opinions on the merits of the mining project; 2) inhabitants' representations of the distinction between the classic (underground) mining methodology perceived as "true mining" and the modern open pit approach perceived as "fake mining"; 3) inhabitants' opinions on the sustainability v. jobs dichotomy; 4)representations on the need for temporary employment to fill the gap until the recommencement of mining activity; 5) the perceptions on the possibility of returning to previously owned properties should the project fail to ever launch again. The general conclusion is that a switchback to the glocalisation strategy would result in benefits for both the Roşia Montană Gold Corporation and for the local community which is at risk of becoming uncertain, already finding itself in a precarious quality-of-life situation.
\end{abstract}

Keywords: Global strategies, globalisation, glocalisation, community, quality-of-life, community uncertainty

\section{Introduction}

As we concluded in previous works on the Roşia Montană Gold Corporation project (RMGC), Romania has become one of the countries of Eastern Europe most open to various vectors of globalisation, namely 
multinational companies interested in its material and human resources (Pascaru, 2007; Pascaru, 2013a; Pascaru, 2013b). This openness has been particularly beneficial to trans-national companies aiming at the exploitation of national mineral resources. One of the most notorious example is Roşia Montană Gold Corporation who managed to elicit intense controversy in connection to its' unprecedented socio-territorial mutations strategy, including controversial property acquisitions and debatable population relocation strategies. In the present study we'll be reviewing the company's switch from a globalisation to a glocalisation strategy at first, followed by a switchback to the globalisation strategy later on, in order to accelerate the implementation of its project. What proved more successful was the glocalisation strategy, that is the rolling on of the preliminary activities through a well coordinated dialog with the local community and the mobilisation of its resources to serve the company's purposes. This type of strategy involves however large time resources and does not solve all the problems of a company willing to implement a project in a given area. This is the probable reason why RMGC adopted the globalisation strategy in 2013 and tried to lobby the Romanian Parliament for a law favouring the commencement of the project. This new strategy failed however, the company having to reduce its activity and lay people off.

This is the context in which our qualitative research study was undertaken. We'll be looking at the following aspects: 1) the rift between the private and the public opinions on the merits of the mining project; 2) inhabitants' representations of the distinction between the classic (underground) mining methodology perceived as "true mining" and the modern open pit approach perceived as "fake"; 3) inhabitants' opinions on the sustainability $\mathrm{v}$. jobs dichotomy; 4) representations on the need for temporary employment to fill the gap until the recommencement of mining activity; 5) the perceptions on the possibility of returning to previously owned properties should the project fail to ever launch again.

In our analysis the uncertainty / certainty perspective of the community life will be accompanied by that of the quality of life.

\section{The Roşia Montană Gold Corporation project}

RMGC is a joint venture between the controlling shareholder Gabriel Resources Limited of Canada with $80 \%$ interest, the Romanian state-owned National Copper, Gold and Iron Corporation - Minvest S.A. Deva holding a stake of $19.3 \%$ and a mixture of residual shareholders controlling the remaining $0.7 \%$ of stock. The exploitation phase of the mine was planned to commence in 2005 and was to last for a minimal period of 17 years. A short history depicted by the authors in previous works (Pascaru 2013b) shows a 
different development though. RMGC official data ${ }^{1}$ shows that during the period between 1997 and 2002 the company has undertaken geological exploration activities in order to estimate the existing reserves. During this period, in 1999 it obtained state licence no. 47/1999 which allowed it to exploit gold and silver resources within the Roşia Montană perimeter. RMGC-funded archaeological research has begun in the year 2000. Starting with March 2001 the company initiated public consultation (meetings) with regional and local authorities, local inhabitants and with critics of the project, in order to account for the controversial relocation measures it undertook. The company acquired multiple private properties in the area between June 2002 and May 2004, and October 2006 and February 2008 based on a displacement and relocation action plan conforming to World Bank and International Finance Corporation standards ${ }^{2}$. In May 2006, RMGC submitted to the Environment Ministry the Environmental Impact Assessment Report ${ }^{3}$ compiled by a team of Romanian and foreign experts. In July 2007 the company started construction work at the Recea living quarter belonging to the town of Alba Iulia, a family house dwelling intended to accommodate part of the local population displaced from the mining area. The project was inaugurated in May 2009. Three years after the submission of the Environmental Impact Assessment the Romanian Environment Ministry restarted the licence granting procedures, a final decision having not been issued to this day. Street protests took place during the fall of 2013, events during which the Parliament was accused of trying to enact special interests legislation ${ }^{4}$. Under public pressure Parliament rejected the law (otherwise important for the mining industry) in its existing form.

The mining perimeter of interest includes three communities whose population required major relocation: the village of Roşia Montană which is the commune centre and the two peripheral villages of Corna ${ }^{5}$ and Gura

1 See also http://www.rmgc.ro/proiectul-rosia-montana/ istoria-proiectului-rosiamontana.html (accessed on August 2016).

${ }^{2}$ See also International Finance Corporation: Handbook for Preparing a Resettlement Action Plan. Available

http://www.ifc.org/wps/wcm/connect/22ad720048855b25880cda6a6515bb18/Resettlement Handbook.PDF?MOD=AJPERES (accessed on August 2016).

${ }^{3}$ See also Environmental Impact Assessment for Roşia Montană Project. Availble at: http://en.rmgc.ro/rosia-montana-project/environment/environmental-impact-assessment.html http://en.rmgc.ro/rosia-montana-project/environment/environmental-impact-assessment.html (accessed on August 2016).

${ }^{4}$ See Comisia specială comună a Camerei Deputaţilor şi Senatului, Raport referitor la Proiectul de lege privind unele măsuri aferente exploatării minereurilor auro-argentifere din perimetrul Roşia Montană şi stimularea şi facilitarea dezvoltării activităţilor miniere din România, noiembrie 2013. Available at:

http://www.cotidiantr.ro/redactie/raport.pdf (accessed on August 2016).

${ }^{5}$ It includes the Bunta settlement. 
Cornii. The inhabitants' were offered the displacement option (exchanging properties for one offered by the company in one of two locations - Recea, next to the town of Alba Iulia mentioned before, or Piatra Alba (White Rock) - a local area intended for residential development), or the relocation option (being paid in cash and left to buy a property of their choosing in a different area).

\section{Globalisation, glocalisation and community uncertainties}

We stand by our conviction that the community of today's Roşia Montană is the direct expression of the globalisation and glocalisation processes it was submitted to (Pascaru 2013b).

We made the observation before that the process of globalisation seems to challenge the multitude of theoretical and methodological efforts undertaken by the social science (Pascaru 2007). Some theoretical difficulties have been signalled before by Van Der Bly who concludes that through its content, the sociological concept of globalisation offers both advantages and disadvantages of an undefined subject, one of the advantages being that of having the liberty to approach the context under a wide variety of modes and perspectives - which in itself can be an interesting intellectual exercise for a perspective like the one sociology has (Van Der Bly, 2005, p. 879).

As we mentioned also in the book Glocalizare românească (Pascaru, 2013b) the themes of the last decades include the relationships between globalisation and localism or local culture, some of Schuerkens (2003a; 2003b) observations being interesting to recall in that regard. It is about the context in which the term of glocalisation is being put into circulation. The term has itself multiple meanings and dimensions and is connected to different practices that imply either the adaptation of the local to the global or that of the global to the local's specific (Wakefield, 2007; boyd, 2006; Knödler şi Albertshauser, 2001; Swyngedouw, 2004; Sucháček, 2008; Novak, 2005). Of particular interest for our analysis are the observations of Sucháček who starts his approach to glocalisation by delimiting the fordism from the post-fordism. The two periods are being treated as distinct in the evolution of the contemporary society, especially when talking about the mutations that took place in the hierarchy of the decisional levels. Sucháček appreciates that one of the most important characteristics of the fordist period was the dominant position of the state in the formation of the socioeconomic and political reality, the national state being conceived as an almost natural scale of managing the national and international phenomena alike. The crisis of the fordism and the ascension of the post-fordism involved a substantial territorial re-scaling of a series of regulations. In this context is the glocalisation phenomenon that takes shape, phenomenon that 
should be understood as a process and which implies several economic, institutional and socio-cultural connotations. The particular forms of global processes according to Sucháček may be identified in tangible settings while the polarisation local-global becomes less and less distinct (Sucháček, 2008 p.12).

In fact, and synthetically speaking, the globalisation and its vectors (multinational companies) may act via the national governments which in their turn oversee the local structures and the enforcement means for their behaviour. In the case of glocalisation the multinational companies conquer first the local and regional communities and use them to create pressure on national governments to enact special interest legislation. There are two strategies involved here we believe: that of globalisation and that of glocalisation, strategies through which we can analyse any penetration attempt by the global on the local, just like in the case of RMGC.

In analysing RMGC's strategy dynamics one can notice that the entry of the Canadian company in the Romanian space has been implemented in line with a globalisation strategy, that is starting with the national government from where the necessary licences were needed and continuing towards the local communities that were to be affected by the project. Subsequently the company started working well with local communities and employing a high professional attitude as part of what we view as a successful glocalisation strategy, an example being the successful property acquisition and population relocation program the result of which is visible in the new Recea quarter of the town of Alba Iulia.

The switchback to a globalisation strategy in the fall of 2013 does not come across as an inspired idea. The company approached the state once again for favourable legislation. The Parliament prepared mining legislation that ultimately failed to pass as result of public and NGO protest. The public debate has brought to surface several controversial aspects of the Canadian majority shareholder's evolution in the Romanian space.

Following the setback some existing tendencies which we signalled in previous studies (Pascaru, 2007; Pascaru, 2013b) intensified within the Roşia Montană community and some new ones emerged, like that of the increase in the number of cases of individual public personality splitting and that of the increase in the uncertainty in the future of the community. Other aspects regard the resulting changes in the quality of life of the inhabitants.

We open a parenthesis here to mention that during the 20th century the problem of the quality of life has been assumed by various domains of study: sociology, social assistance, environmental science. Sociology has been called upon to evaluate social changes by accounting for different factors that have to do with social cohesion, education, culture, etc. Environmental science has developed numerous natural environment quality 
indicators and assessed the society's capacity to undertake sustainable economic activities (Carr et al, 2003, p. 3; Buţiu, 2014, p. 65). From all these approaches, we take particular interest in Gordon Marshall's one in which the quality of life a person has corresponds to his/her liberty to choose a particular lifestyle over another (Marshall, 2003, p. 78). One also needs mentioning that during the last three decades, the subject of quality of life has become a major topic of interest at the European Community level (Fahey et al., 2003, pp. 9-11), an aspect that requires consideration in view of the fact that Romania's globalisation trajectory is now influenced by its' status as an European Union member.

As a whole and regardless if the objective is the general quality of life or the standard of living, the interviews which we will be referencing next allow us to categorise the community of Roşia Montană as both an uncertain and a vulnerable community.

\section{A qualitative research study at Roşia Montană}

Following the failure to elicit a law favourable to the commencement of mineral exploitation, RMGC started to reduce both its exploratory and operational activity. The workers have been sent into technical unemployment. Our research took place in this context and consisted in 29 semi-structured interviews, the majority of respondents being laid-off workers from RMGC. The interviewers were two graduate students on Sociology at the University of Alba Iulia, Ioana Sturza and Simona Stan. We'll be presenting some of the most interesting themes that emerged from the survey next, themes that were mentioned in the introduction of this study.

\section{Private and Public positions towards RMGC}

One of the explanations identified by our graduates for the rift between the personal wishes of their interviewees and their public position on the project was that of the general climate surrounding the project: "That happens because there are a lot of speculation, gossip and mean things and in their soul [people] wish that [the project] starts, because it would bring better salaries and a future for the family." (M[ale], age 38, unemployed). Another explanation has to do with the lack of information about the project: "I believe that because they didn't participated to the meetings and the gatherings organized in the community, they are not sufficiently informed about the project." (F[emale], age 34, unemployed); "The majority of the people wish for the start of the project. Probably those who do not wish it, do not say the truth, are not well informed or have been influence by others ${ }^{6}$." (F, age 38, unemployed). The problem of external influence is being also

\footnotetext{
${ }^{6}$ Reference to the activists against RMGC.
} 
remarked by another respondent: "People that say this and that are probably influenced from somewhere else." (M, age 30, unemployed).

Another explanation identified by our collaborators was certain behaviour of the company in the process of hiring locals: "I don't agree because they made too many tricks. [For example] they hired more people from other areas and the locals were forced to go and look for work abroad." (F, age 23, unemployed).

Worries about pollution and about the lack of sustainability of the project were also invoked by some of the inhabitants: "Because they're afraid of all that is harmful in the first place and secondly because they want that the project lasts a long time, so that will be work for us and our descendants [alike]." (M, age 44, driver).

\section{"True mining" v. "fake mining"}

In the mining tradition of Roşia Montană value was placed on a certain type of personality that signifies "true" mining: a hard worker toiling in underground galleries, dedicated to his work and sparing no sacrifice in meeting his goals. This is being contrasted in community discourse with the "fake" miner that is one to be employed in the surface (open pit) operations. We observed voices that argued for a re-launching of the project employing "true" miners rather than with "fake" ones. Ioana Sturza and Simona Stan explored this theme during their interviews. Generally speaking it was considered in 2014 that the traditional mining with "true" miners was not feasible anymore in Roşia Montană: "Yesterday's miners will never come back; today's miners we have to have them pre-made... for to be a miner is not easy, regardless of the conditions one works in." (M, age 45, unemployed). The option for the traditional mining and its workers has to do in respondents' opinion with either the relationships with RMGC or with the debatable sustainability of the project: "Some people think that way for they may have had bad experiences with someone in the company... phoneys can be found in all firms and companies in the world. This is the competition and the market economy. Before, the exploitation was done by the communists, now it's the capitalists, two different systems" (M, age 38, unemployed). The issue of workers hired from outside the area also came up: "I think is because they hate the company [because] they hired all kinds of people from different places and left aside the ones in the village" (F, age 28, unemployed).

\section{Sustainability and work alternatives}

One of the problems in Roşia Montană was in connection to the choice between a short term project option proposed by RMGC and that of leaving in search of employment abroad. The latter was disliked for in the interviewees opinions would mean abandoning the families in the first place: 
"Yes, the separation from the loved ones is far more painful and harder than any work, no matter how hard it would be!" (F, age 48, unskilled worker).

The difficulties encountered in the countries where the workers went were also a contributing factor for the RMGC option: "Would be good to start the project so that people don't leave their homes... Even abroad you don't find work that easy anymore." (M, age 30, unemployed).

There was also hope that the project will engage a wider scope of development in the region: "...In the world there are a lot of mining areas and with responsible mining, the area could develop, and the basis for tourism and services may be laid. Without mining, all area would be deserted" (M, age 38 unemployed).

Some of the pressure even for a short term project option came from the debt situation of some villagers: "...Many have loans... Many started building their homes and now that the company closed they can't finish them, so it is normal they'll settle for a short term option to pay some of their debts, to finish their houses, to live, of course." (F, age 30, sales worker).

There were also voices against the short or medium term project option having hard to see consequences for future generations: "...They should think about the long term future. It is not good to think only at yourself... You have to also think at the future generations, because they would like to live at home too, close to their families" (M, age 38 unemployed). Another argument was in favour of those who had better success at working abroad than those who stayed home: "...In my opinion, those that want to leave, they'll leave anyway... I know people who had chances of being hired by the company, but they preferred abroad and don't regret it, because they made it. Should they have stayed, I don't think they would have what they have now..." (F, age 23, unemployed).

\section{Waiting for a project re-launch or looking for another job?}

As we mentioned before, the failure of the globalisation strategy employed by RMGC led to a reduction in local employment. A new dilemma arose: those being laid off should wait for a project re-launch or should they start looking for a different job? The number of the "wait" option supporters was very small at the time of the interviews, in the spring of 2014. They mostly motivated their option with the difficulty of finding alternative employment in the area: "We hope that [the project] starts, to work here, because here would be better. To start looking elsewhere is hard, because you don't find..." (M, age 30, unemployed).

Some supporters of the looking-for-another-job option invoked the lack of political will to restart the project in an election year: "They should look for work. Being an election year no one dares to release the project. At stake are many votes that would be lost if the project is approved, but if they 
don't approve it, would be a bad signal for the business environment. Thus it will be another one or two years of uncertainty and the unemployment benefits don't last long, a family cannot live from unemployment benefits. So they should go." (F, age 32, unemployed).

Other respondents did not lose hope completely and for those, the looking-for-another-job option was a temporary solution until the project restarts: "Who has the opportunity to find [work] somewhere else would be doing well [to hire] because we don't know what the company will do, but if it restarts, we'll be called back" (F, age 34, unemployed).

\section{A possible return to Roşia Montană?}

Having a community under globalisation pressures face a hypothetical situation is an efficient exploration technique of their opinions and attitudes in our opinion. This technique has also been employed in the 2014 interviews. The question designed to elicit such a hypothetical situation was: In the case where RMGC pulls back, do you believe there will be people interested in recovering their properties?

On the whole, the answers of respondents rejected the likeliness of inhabitants reclaiming their properties. Firstly because they would be doing better where they lived at that point: "No, I don't think they would be. I know many who would sell and leave the area... And of coming back, if the project doesn't start, come back to what? To jobless and poverty?" (F, age 32, unemployed) "... Those that sold, they couldn't even if the would. But trust me, you cannot compare the conditions in Recea with those in Rosia Montană if the project doesn't start" (M, age 38, unemployed). Secondly because the money have already been spent: "...I don't think they still have enough money to buy back their properties, and the company clearly won't take the loss" (F, age 25, unemployed).

Those interested in returning to their old properties could have done that out of pride or to have a holiday house in Roşia Montană: "If they would want to reclaim their land, they would do it just out of pride or to have a place for the holidays..." (F, age 34, unemployed). "Yes, just to have a holiday house, I don't think there would be another reason" (F, age 25, unemployed).

A special situation arose for those who opted for a displacement to the Piatra Alba local development site where nothing had been built yet: "... Possibly those that sold but have not moved yet [because] they have not received their new place at Piatra Alba..." (M, age 30, unemployed).

Also worth mentioning is the case of those that accepted moving to the Recea quarter, near the town of Alba Iulia, but were dissatisfied with the quality of development there: "Yes, some are dissatisfied with the way the 
houses were built (for example at Recea, Alba)..." (F, age 48, unskilled worker).

And there also was the firm opinion that RMGC will never pull back from the area: "Surely the company will never pull back. The project will start eventually and people don't have a way of recovering their properties. If the project will start, they will come back for they would surely have a job." (F, age 23, unemployed).

\section{Conclusion}

As resulting from our study also, the utilisation of the global strategy perspective in analysing some multinational companies is beneficial. Each strategy may succeed or may fail, but each time there will be a community impact, a decrease or an increase in the uncertainty of the future the community faces. Starting from these general premises we are synthesizing next the most relevant aspects of our research.

In explaining the rift between the private and the public opinion of the inhabitants on the project the reasons most frequently invoked were: a) the general climate surrounding the project characterized by conflicting and confusing messages (gossip, rumours); b) the lack of accurate information about the project; c) the perception of unfair hiring practices of the company which sometimes seems to favour workers outside the community; d) worries about the pollution and other consequences in opposition to the acute need for employment.

In the matter of "true" versus "fake" mining, one remarks the respondents' appreciation that a return to mining with "true" miners is no longer possible in Roşia Montană. The existence of opinions for the return to traditional mining had in respondents view to do with either the relationship to RMGC or with the sustainability concerns of the project.

The opinions as to the choice between sustainability and immediate employment which favour the latter were explained through the dilemma of looking for work abroad and through the reality of financial pressures of people in debt. There were nevertheless opinions against short term employment at the expense of detrimental consequences for them and for future generations.

The representations around the need for a different job were structured around the inclination to look for another job, either because the perceived chances of project re-opening were slim or because it would provide temporary assistance should the company reopen after all.

The appreciation of the chances of people reclaiming their original properties in the area were generally sceptical either because people who left seemed satisfied with their current situation or because some spent enough of the proceeds to make a buyback unlikely. Those that would be interested in 
recovering their properties would probably be doing it out of pride or to have a holiday home in Roşia Montană. A particular motivation for reclaiming their properties would have those that did not received the promised accommodation to the local Piatra Alba site or those who were dissatisfied with their dwellings at Recea quarter, near the town of Alba Iulia.

Two additional general conclusions can be drawn also. The first one concerns the evolution of community's uncertainty as a result of the whole debate. The community of Roşia Montană being at risk of becoming an uncertain community it would seem wise for the company to return to a glocalisation strategy. The costs of such a switchback may be debatable, but the issue certainly deserves a sociologist's attention. The second general conclusion pertains to the quality of life of the community members which not only supports the idea of an uncertain community but also warrants the worry of a vulnerable community. As we stated in previous works, the economic and social situation of the inhabitants is negatively affected by the acute lack of employment, which in turn affects the quality of life and the level of poverty (Pascaru, 2013b). The vulnerability of the Roşia Montană community is increased by community uncertainty in the context where, as Marshall said, the quality of life of an individual corresponds to the liberty of that individual to choose a life style over another. This is why we stand by our conviction that a switchback in RMGC's strategy from globalization towards glocalisation would result in an alleviation of the uncertain community status that the community now has by allowing the inhabitants better choices of their lifestyle. Only this step in itself is not sufficient, the other necessary requirement is that the government of the country gathers the political will to take a firm decision to either allow the project to start, or terminate it once and for all.

Reviewing the results of a previous Roşia Montană research study may prove useful for those who aim to examine a globalization-glocalization process in post-communism Romania step-by-step. Also, the authors consider that it may be a good time for a fresh look at how the reduction to almost zero of the RMGC project activity impacted the community in the area. ${ }^{7}$.

\footnotetext{
7 On February 15th, 2015 the company issued a statement announcing that $70 \%$ of the employees would be laid off. In another statement of April 1st, 2015 it mentioned „the initiation of the collective layoff procedure for a percentage of approximately $35 \%$ of the remaining employees of the company”. The company also stated that „Roşia Montană Gold Corporation reaffirms its willingness to develop the most modern gold mine in Romania, and hopes that the decision makers will engage in consultations as soon as possible". See http://www.rmgc.ro/ and http://en.rmgc.ro/index.html.
} 


\section{References:}

1.boyd, D., 2006: „G/localization: When Global Information and Local Interaction Collide”. In: O'Reilly Emerging Technology Conference, San Diego, CA, March 6. Available at: http://www.danah.org/papers/Etech2006.html (accessed, Jun 2013).

2.Buţiu, C.A., 2014: Bunăstarea, incotro? Spre o nouă paradigmă în politicile sociale. Cluj-Napoca: Presa Universitară Clujeană.

3.Carr, A.J., Higginson, I.J. \& Robinson, P.G., 2003: Quality of Life. London: BMJ Books.

4.Fahey, T., Nolan, B. \& Whelan, C.T., 2003: Monitoring Quality of Life in Europe. Luxembourg: Office for Official Publications of the European Communities.

5.Knödler, H. \& Albertshauser, U., 2001: Glocalisation, Foreign Direct Investment and Regional Development Perspectives: Empirical Results for West German Regions. Hamburg, Hamburg Institute of International Economics. Available at:

6.https://www.econstor.eu/dspace/bitstream/10419/19434/1/117.pdf (accessed in September 2016).

7.Marshall, G., 2003: Dicţionar de sociologie. Bucureşti: Editura Univers Enciclopedic.

8.Novak, B., 2005: "Transformative school in the glocalisation process". In: Managing the Process of Globalisation in New and Upcoming EU Members. Proceedings of the 6th International Conference of the Faculty of Management Koper Congress Centre Bernardin, Slovenia, 24-26 November 2005. Available at: http://www.fmkp.si/zalozba/ISBN/961-6573-03-9/novak.pdf (accessed in September 2016).

9. Pascaru, M., 2007 : Habitatul risipit de globalizare. Impactul psihosocial şi rezidenţial al proiectului Roşia Montană Gold Corporation. Cluj-Napoca: Editura Argonaut.

10. Pascaru, M., 2013a: Romanian Glocalization. Case Study on the Roşia Montană Gold Corporation Mining Project. In: Revista de Cercetare şi Intervenţie Socială, 43, pp. 39-48.

11. Pascaru, M., 2013b: Glocalizare românească. Impactul comunitar al proiectului Roşia Montană Gold Corporation. Cluj-Napoca, Limes.

12. Schuerkens, U., 2003a: Social Transformation Between Global forces and Local Life-Worlds: Introduction. In: Current Sociology, MayJuly 2003, Vol. 51, pp. 195-208.

13. Schuerkens, U., 2003b: The Sociological and anthropological Study of Globalization and Localization. In: Current Sociology, May-July 2003, Vol. 51, pp. 209-222. 
14. Sucháček, J., 2008: On the Emergence of Glocalisation. MPRA Paper No. 10025, posted 14 August 2008. Available at: http://mpra.ub.unimuenchen.de/10025/ (accessed in September 2016).

15. Swyngedouw, E., 2004: Globalisation or 'Glocalisation'? Networks, Territories and Rescaling, Cambridge Review of International Affairs, Volume 17, Number 1, April 2004, pp. 25-48.

16. Van Der Bly C. E., M., 2005: Globalization: A Triumph of Ambiguity. In: Current Sociology, November 2005, Vol. 53(6), pp. 875-893.

17. Wakefield, R. I., 2007: "Globalisation, Glocalisation, and Corporate Reputation: What Does it all Mean for the Multinational Entity?” In: 14th International Public Relations Symposium (14th Annual BledCom) "Impact of Globalization on Public Relations", Bled, Slovenia, 6 - 8 July 2007. Bled: Digital Library in Public Relations. Available at:

18. http://www.bledcom.com/uploads/papers/Wakefield.pdf (accessed in Jun 2013). 